\title{
Preservice Teachers' Experience in Learning and Teaching Social Sciences in Secondary Education Using the Inquiry-Based Learning Method
}

\author{
Gila Cohen Zilka ${ }^{1}$ \\ ${ }^{1}$ Achva Academic College, Bar-Ilan University, Israel \\ Correspondence: Gila Cohen Zilka, Achva Academic College, Bar-Ilan University, Israel.
}

Received: April 21, 2021

doi:10.5539/ies.v14n9p44
Accepted: June 14, $2021 \quad$ Online Published: August 25, 2021

URL: https://doi.org/10.5539/ies.v14n9p44

\begin{abstract}
The ability of teachers to adopt inquiry-based learning depends to a large extent on their knowledge, skills, perception, and attitudes toward it. Therefore, it is important to explore the preservice teachers' experience of learning and teaching with this method, with the assistance and mediation of preservice teachers' educators. Preservice teachers participated in a blended course to acquire the teaching skills needed for inquiry-based learning, at the same time gained experience teaching based on this approach in high schools in Israel. The study included 120 preservice teachers who completed questionnaires at the beginning of the course (first measurement) and at the end of the course (second measurement). The findings show that between the two measurements there was an increase in positive attitude toward inquiry-based learning and teaching. Most of the participants noted the difficulties they encountered in applying the inquiry-based method in teaching in schools. In the course of teaching with this method, they acquired tools to cope with these difficulties.
\end{abstract}

Keywords: inquiry-based learning, blended courses, preservice teachers, social sciences

\section{Introduction}

Inservice teachers play a key role in mediating between subject matter, inquiry-based learning, and learners. Inquiry-based learning is embedded in the curriculum of the social sciences in Israel. The ability of inservice teachers to assimilate inquiry-based learning depends to a large extent on their knowledge, skills, perception, and attitudes toward inquiry-based learning (Angeli \& Valanides, 2009; Durish, 2013; Tyner, 2014). Therefore, it is important to explore the preservice teachers' experience of learning and teaching with this method, with the assistance and mediation of preservice teachers' educators. The purpose of this study was to examine the attitudes of preservice teachers regarding the experience of learning and teaching with the inquiry-based method. The research focused on preservice teachers who were studying to become teachers of social sciences. They participated in a blended course to acquire the teaching skills involved in the inquiry-based learning approach, at the same time practicing teaching with this approach in high schools in Israel.

\subsection{Inquiry-Based Learning}

The term "inquiry-based learning" was coined by Dewey (1938). Researchers (Barron et al., 2008; Dewey, 1938; Loyens \& Rikers, 2011) claim that the research process begins with identifying a question or problem, and progresses through planned stages of data collection, data processing, analysis and representation of data, answer, or solution - using reflection, high-order thinking strategies, and new knowledge construction processes. The nature of inquiry varies from one field of knowledge to another. In natural and social sciences, research is usually empirical, and in the humanities it is based on analysis, interpretation, comparison, synthesis, and contraposition of texts of different types. Naturally, it is possible to engage in inquiry-based learning both modularly and on a limited scale by focusing on one or several parts of the complete process. For example, in a discussion of a complex issue, it is possible to engage only in the formulation of theoretical or empirical research questions.

Educators have been showing interest in inquiry-based learning for decades. Schwab's (1962) view of inquiry-based learning is based on his conception of science being composed of disciplines, so that in every discipline there are conceptual structures that determine the questions to be asked, as well as data to be collected and experiments to be conducted. Every discipline has a syntactic structure consisting of processes, methods, and 
criteria that determine how the research will be conducted, evidence gathered, and conclusions drawn. Inquiry-based learning (Bhagat, 2017; Pedaste et al., 2012) is understood as exploring the world around in ways characteristic of the researchers' work in a certain discipline. The role of the teacher in inquiry-based learning is to assist students, guide, direct, and advise them, stimulate their curiosity, and teach the skills required for research work. It also includes mediating between the students and the content, and guiding the students through the various stages of the research project to the final product. It involves enabling students to make informed use of data, including its various types and representations, to integrate information collected from various sources, to analyze and interpret the information, to transform information into knowledge in a meaningful process, and make use of it (Angeli \& Valanides, 2009; Durish, 2013; Tyner, 2014). The research strategy includes focusing on the topic of research using skills of question formulation, locating the information, data collection and integration, data analysis, presentation of arguments, etc. (Mäeots et al., 2012; Pedaste et Sarapuu, 2008; Pedaste et al., 2015; Scanlon et al., 2011).

Researchers (Alfieri et al., 2011; Furtak et al., 2012) found that inquiry-based learning leads to better results than other forms of learning without inquiry and discovery. Researchers (Liu et al., 2007; Meyers, 2008; Oriogun et al., 2005; Pittman \& Richmond, 2008; Robinson \& Hullinger, 2008; Young \& Bruce, 2011; Young, 2006; Shea et al., 2006; Rovai, 2007) also noted that in inquiry-based learning the learner must be involved in the learning process, seeking meaning. Involvement in the learning process is derived from both external and internal motivation. Motivation for learning occurs when one is disposed toward it because it gives one pleasure, because one values it or the associated achievement, or because of one's desire to develop, expand, and increase one's abilities, in a process of self-empowerment.

At the same time, researchers (Kirschner et al., 2006; Kirschner \& Van Merriënboer, 2013) criticize research-based teaching and argue that by teaching in this way, teachers engage in less mediation between learners and the subject matter, and emphasize learning processes and skillset the expense of the subject matter. Chinn, Duncan, and Rinehart (2018) state that whereas critics of the method mistakenly identify the way of teaching and learning with minimal guidance, the opposite is true: the inquiry-based way of teaching and learning supports learners' learning processes through extensive mediation and guidance. Researchers (Chinn et al., 2018) argue that many studies indicate that the inquiry-based approach leads to a marked improvement in learning outcomes. The improvement was noted in the assessment of student achievement on standardized tests, which usually measure relatively simple learning objectives, and also using assessment tools for examining complex learning objectives that are more appropriate for inquiry-based learning: thinking abilities, problem solving abilities, complex explanations of phenomena and concepts-resulting in much stronger effects.

In many parts of the world, teaching and learning methods involving active participation of the learner rather than "passive listening," such as the inquiry-based method, are partially implemented (Nir et al., 2016; OECD, 2019). A TALIS survey (2018) conducted in 48 countries shows that most teachers (66\%) use assessment practices typical of traditional frontal learning, as opposed to using teaching and assessment practices that encourage thinking, independent learning, retrieval and processing of information. Therefore, it is important to increase the e-Readiness of preservice teachers, allow them to observe the integration of digital environments in teaching and learning in the course of their training to experience these environments, and to adopt effective teaching and learning methods, custom-tailored to learners.

\subsection{Learning Community}

Researchers (Capar \& Tarim, 2015; Gillies \& Ashman, 2013; Loyens \& Rikers, 2011) claim that inquiry-based learning in a group leads to intensification of the learning process of every participant and of the group as a whole. Vygotsky (1989) saw learning as an interpersonal process, not merely a cognitive-personal one. Vigodsky explained learning as a cognitive acquisition of symbolic systems, through personal interaction between the learners and their peers, until symbols are internalized and become available to the learners to make use of them (Pea, 1993). Researchers of organizations (Argyris \& Schon, 1996; Weick, 1997) have suggested looking at a team, group, class, or organization as independent entities capable of learning and developing beyond the development of the individuals who make up these groups. Researchers (Ascough, 2007; Baker, 2010; Engstrom et al., 2008; Snyder, 2009; Splitter, 2009; Zilka et al., 2019; Zilka \& Zeichner, 2017, 2016) have defined cooperative learning through the creation of a space for collaborative, educational, and free discussion. Collaborative discourse enriches the process of individual and group learning. Researchers (Billings \& Halstead, 2009; Cole, 2009; Feldman, 2007; Jelfs et al., 2009; Lawrence \& Sankey, 2008; Lee, 2008; Oliver et al., 2009) found that the unique characteristics of a learning community may create in students a sense of personal empowerment that enhances the learning process and enriches their lives. A learning environment is one that enables a dynamic process, in which students feel safe to be active participants (Husaj, 2016; Maurice \& 
Harriett, 2006; Splitter, 2009; Zins, 2004).

The teacher must enable situations that encourage collaboration between students. In case of confrontation between group members, the teacher must help them negotiate and reach an agreed-upon solution (Salman, 2006). To encourage students to actively participate in the discussion, the teacher must give a personal example of active participation by showing interest and curiosity, asking questions, raising dilemmas, being a partner in learners' forums, etc. (Sharan, 2014). Researchers (Liu et al., 2007; Rovai et al., 2004) found that a teacher who encourages the creation of a learning community encourages communication between students, which then leads to meaningful learning. Researchers also found that a successful learning community includes two main indicators, a social index (active involvement in the community), and a study index related to the content studied. Robinson et al. (2008), Rovai (2007), Shea, Li, and Pickett (2006), Young (2006), and Young and Bruce (2011) found that students who are actively involved in the learning community perform significant tasks better than those who are not, are likely to feel a sense of belonging as opposed to alienation and isolation, and persevere and succeed in the learning tasks.

\subsection{Inquiry-Based Learning in Teacher Training and Blended Courses}

Training of preservice teachers with the inquiry-based method. Researchers (Bai, 2019; Desimone, 2009; Holmes et al., 2018; Kennedy, 2016; Lampert, 2010; McDonald et al., 2013; Sung et al., 2016; Tsai \& Tsai, 2019; Zilka, 2020a, 2020b; Zilka et al., 2018; Zilka et al., 2019) claim that the preservice teacher training process should be based on experiencing the inquiry-based learning method, with emphasis on the use of pedagogical models for effective integration of this method in teaching, while addressing the needs of different learners. Collaborative learning communities should emerge, making it possible to identify the barriers that preservice teachers encounter in teaching and learning with the inquiry-based method. The objective is for the training process of preservice teachers to increase their readiness for an effective integration of inquiry-based learning when they start working as inservice teachers. Researchers affirm that today there are fascinating and varied options for inquiry-based learning exploration and sharing that are not limited in time or place (Ertmer \& Ottenbreit-Leftwich, 2010; Feenberg, 2010; Mahler, 2012).

The preservice teachers who participated in this study attended a blended course in inquiry-based learning in social science. Researchers found that studying in a digital environment strengthens learning (De Jong et al., 2010; Mäeots et al., 2011). Researchers (Zilka, 2017; Ertmer \& Ottenbreit-Leftwich, 2010; Ashburn \& Floden, 2006) have argued that the digital environment has breached the time and place boundaries of learning. The digital environment serves as the learners' partner in the construction of knowledge, its processing and presentation. The digital environment helps learners carry out reflexive metacognitive processes, processes of self-focus, cognitive processes, and emotional and differential processes. A blended course refers to a combination of face-to-face and virtual learning. The learners meet face-to-face regularly, the course has an active website, and discussions are held in a forum on the course website and continue face-to-face. This combination is expected to enrich the relationship between the teacher and the learner within the learners' community (Anderson et al., 2001; Garrison \& Kanuke, 2004; Groen \& Li, 2005; Zeichner \& Zilka, 2016; Zilka et al., 2019; Zilka \& Zeichner, 2017, 2019).

\subsection{The Present Research}

The purpose of the present study was to investigate preservice teachers' attitudes regarding learning and instruction using the inquiry-based learning approach, and their attitudes toward the learning and teaching experience using this method, facilitated and mediated by the preservice teachers' educators. Preservice teachers participating in the present research were studying to be social science teachers. They attended a course to acquire teaching skills in inquiry-based learning, and at the same time acquired experience with this approach by teaching in secondary schools in Israel.

\subsection{Research Questions}

Research questions were derived from previous studies (Zeichner \& Zilka, 2016; Zilka, 2017; Zilka et al., 2019; Zilka \& Zeichner, 2017, 2019).

1) What characterizes the preservice teachers' perception of inquiry in learning?

2) What characterizes the preservice teachers' perception of inquiry in teaching?

3) What are the difficulties that arise in the implementation of inquiry-based study in the school?

4) What was the most meaningful experience preservice teachers had while learning with the inquiry-based method in the blended course? 
5) What was the most meaningful experience preservice teachers had while teaching with the inquiry-based method in school?

6) Did the process of learning the inquiry-based method in a blended course help them consolidate their role as a teacher in the digital age?

\section{Method}

The sample of this study consisted of 120 preservice teachers who completed two questionnaires, one before the beginning of the blended course, and one after it ended.

The course was an annual one, taught simultaneously at two institutions of higher education in Israel. We conducted a content analysis of the answers in the 240 completed questionnaires.

The data were collected in 2017.

Qualitative analysis: A discourse analysis was performed on the collected data based on the approach of Adler and Adler (2008), Atkinson and Delamont (2006), Chenail (2012), and Hammersley (2008). Distinct elements were identified and themes formulated. The process was iterative and continuous, and at the end of it data were coded into consolidated themes, showing sensitivity to context and its place in the construction of reality.

The interviews were analyzed using thematic analysis (Boyatzis, 1998; Braun \& Clarke, 2006; Crabtree \& Miller, 1992), which involves identifying themes in the data through a recursive process of careful reading and re-reading of the transcribed interviews. Based on Braun and Clarke (2006), our process included familiarizing ourselves with the narratives, generating initial codes, collating codes into potential themes, assembling the data relevant to each potential theme, and finally generating a "thematic map" for the analysis.

\subsection{Population}

The sample included 120 preservice teachers studying at two academic institutions for teacher training in Israel to become teachers of social sciences. Of the respondents, $78 \%$ were women; $43.3 \%$ were aged $20-30,40.3 \%$ aged 30-40, 16.4\% aged 40 and over. Preservice teachers were in the last year of their studies toward a teaching certificate. All participants had a bachelor's degree, $32 \%$ had a master's degree, and $20 \%$ had a $\mathrm{PhD}$.

\subsection{Research Tools}

The research tools were derived from previous studies (Zeichner \& Zilka, 2016; Zilka, 2017; Zilka et al., 2019; Zilka \& Zeichner, 2017, 2019).

The purpose of the questions in the questionnaire and in interviews was to expose the attitudes of preservice teachers studying to be social science teachers toward learning and teaching with the inquiry-based method. One of the study objectives was to check whether there were changes between the measurements at the beginning and the end of the study. Therefore, the questions in the first and second measurements were the same.

1) Questionnaire with open-ended questions. The questionnaire was administered twice, before the start of the blended course and at the end of the course. The questionnaire included several parts:

- Learning: What is your opinion regarding inquiry-based learning as an integral part of your studies?

- $\quad$ Learning at school: What is your opinion regarding inquiry-based learning as an integral part of the learning of students in school?

- Teaching experience: What is your most meaningful experience teaching with the inquiry-based method at school?

- Learning experience: What is your most significant experience learning with the inquiry-based method in the blended course?

- $\quad$ Did the process of learning with the inquiry-based method in the blended course help you in shaping your role as a teacher in the digital age?

2) Personal interviews: 30 of the preservice teachers who completed questionnaires were randomly selected to be interviewed. The interviews were semi-structured and comprised the subjects included in the research parameters, but the order of the questions was based on the dynamics of the communication with the interviewees. The interviewees wanted to share their positive and negative experiences, and some went into detailed descriptions. Interviews lasted 15-25 minutes.

3) Nine questions about personal status, demographics, age, sex, year of study, etc. 


\section{Findings}

The questionnaires and interviews produced the following findings.

1) Preservice teachers were asked what their opinion was regarding the inquiry-based method as an integral part of their studies.

Answers to the first questionnaire, before the beginning of the blended course, revealed that $60 \%$ of preservice teachers had a positive attitude toward learning using the inquiry-based method, and $40 \%$ answered that they preferred frontal learning because they felt more confident in understanding the teacher's requirements. These respondents also thought that in frontal learning they would be able to achieve better outcomes than with inquiry-based learning. Half the respondents stated that they felt greater freedom to learn at a higher level with the inquiry-based method than in frontal learning. Preservice teachers noted that with the inquiry-based method they have a choice between different options, different texts, and different tasks.

Answers to the second questionnaire at the end of the blended course taught in academia were more specific. They revealed that most the preservice teachers had a positive attitude toward learning using the inquiry-based method: $75 \%$ approved of inquiry-based learning, and $25 \%$ opposed it. But the answers to the second questionnaire were more specific than to the first one, and statements were more focused rather than generic. Preservice teachers described difficulties, such as complexity, lack of clarity regarding what the teacher wanted, and communication overload on the course site.

One preservice teacher, who changed his mind between the first and the second questionnaire, wrote: "I study and work, and it is difficult for me to free time for assignments in the course of the semester. In the course, there were papers throughout the semester, and cooperation with others on the course site made it difficult for me, but in retrospect one can learn from it, it provokes curiosity and provides satisfaction."

Below are other sample answers from the questionnaires:

- In inquiry-based learning I feel that I understand the material much better than in other types of learning.

- Inquiry-based learning provokes curiosity and a willingness to invest effort. Without a doubt, I had to spend a lot more time with inquiry-based learning than with frontal learning.

- I see inquiry-based learning as an essential part of my life. This is the best method for me, exploration and experimentation, and not memorizing content.

- I felt a sense of independence, freedom of thought, creativity.

- The experience itself is unsettling. There are positive things, but on the other hand there are also negatives. I felt frustrated after every lesson because I didn't understand what should be done, and over time I realized that this is the point of the inquiry-based method.

- This method of learning combines the development and assimilation of high-level thinking and analysis habits, which are important for me to develop and implement. In the course of the inquiry, it is possible to achieve a deep understanding of the material.

2) Teaching at school: What is the opinion of preservice teachers on inquiry-based learning as an integral part of students' studies in schools?

Answers to the first questionnaire, before the beginning of the blended course and teaching experience in schools, revealed that $58 \%$ of preservice teachers had a positive attitude toward teaching in school using the inquiry-based method, and $42 \%$ answered that they preferred frontal teaching.

Answers to the second questionnaire, at the end of the blended course and after the experience of teaching in a school, were more specific. They revealed that $70 \%$ of preservice teachers used the inquiry-based method to teach in school, and $30 \%$ were against it, in contrast with the answers to the first questionnaire, where only $58 \%$ were in favor of teaching with the inquiry-based method. But the answers to the second questionnaire were more specific than to the first one, and statements were more focused rather than generic.

Below are sample answers from the questionnaire:

- Today there are many databases on the Internet, and students can search for and find relevant materials on subjects that interest them, so they must be taught research processes. The problem is their lack of motivation, of willingness to invest time in inquiry-based learning beyond school hours. They are busy with after-school activities, and they don't want to invest beyond the minimum required of them, so they prefer clear assignments rather than research assignments. 
- I like to learn like this, but I find it difficult to teach this way.

- It didn't work for me. The students found it difficult to formulate an inquiry question, to process into knowledge information from articles that were not taught in the lesson, and to formulate ideas.

- It requires a lot more effort and creative thinking from the teacher, and time to evaluate the products.

- At some point I almost gave up and wanted to formulate the research question for them, refer them to an article and help them process it, but I took a deep breath and reminded myself of the purpose of the lesson. The purpose was not for me to perform the process for them.

- I felt that the whole process was taking a long time, so I started to invest less in the subject, and rounded some corners, so that the students would finish their assignments.

The focus of the difficulties raised by the students following the experience of teaching in school with the inquiry-based method: difficulty in assessing students' shared outcomes; difficulty in arousing students' motivation, commitment, and seriousness; difficulty in the various stages of inquiry, especially in the formulation of a research question; inquiry-based teaching requires a great deal more effort and much more time than is required by frontal teaching.

3) Learning experience: What was your most meaningful experience in the process of inquiry-based learning in the blended course you took at your institution?

Preservice teachers shared their experiences of inquiry-based learning in the academic course. They responded that they felt they had gone through a significant experience (62\%), developed the skills required to perform research tasks (57\%), acquired problem-solving skills (52\%), and acquired skills for processing and presenting knowledge (38\%). They experienced activating meta-cognitive reflective processes, self-directed processes, and self-awareness cognitive processes $(39 \%)$, as well as skill-sharing and collaboration with other preservice teachers $(57 \%)$.

Examples of answers:

- My significant experience is the ability to analyze the findings and make a synthesis between theory and findings.

- $\quad$ My self-learning and my ability to research a topic in depth, the satisfaction from my product after hard work. I had a sense of self-efficacy.

- In the process of working I felt that there was no clear framework, no close control, that I had to do all the work. I felt stressed, so I turned to friends and we did the assignment together. I felt that it was an exhausting and unclear journey. Inquiry-based learning is an experience that requires self-reflection and deep study of the material.

- Peer learning. The course encourages cooperation in the understanding of assignments.

- The reflective process that I underwent and freed myself from fears that stayed with me since I was a high school student.

- The sharing of assignments on the course site opened up a whole world for me. I was exposed to works that opened my eyes and opened new horizons for developing lessons using the inquiry-based teaching method.

- Following the experience in the course I felt empowered and full of desire to deepen my specialization in the inquiry-based teaching approach.

- At the beginning of the process I felt pressure, fear, curiosity, and fear. At the end of the process I felt great satisfaction.

- Although the learning was not simple, there was always a desire to continue the process, because each stage had an interesting goal by itself.

4) Teaching experience: What is your most meaningful experience in the process of teaching with the inquiry-based method at school?

Preservice teachers shared their experiences of inquiry-based teaching in school. They responded that in their opinion both themselves and their students had a significant experience (48\%); felt satisfaction (32\%); developed meta-cognitive reflective processes, processes of self-direction, cognitive processes, self-awareness (mainly as a result of interaction with students, student comments, etc.) (39\%); and enhanced cooperation between students (50\%). In addition, they also experienced feelings of frustration, despair, and helplessness (40\%).

Examples of answers: 
- The significant experience from teaching in the inquiry-based method was the encouragement of critical and profound thinking in my students.

- $\quad$ The most significant experience was the ability to help students and encourage them to engage in a process of inquiry, although some of them refused and objected at first.

- The most significant experience was not to present students with structured material, but to let them explore the topic, ask questions, and lead them toward a meaningful and experiential process of inquiry.

- I had a sense of mission to convey the joy of inquiry and discovery to the students.

- In the first stage, when I presented the subject, it seemed to me that everyone was enthusiastic. After it was time to experiment with the stages of inquiry and submit products, it seemed to me that everyone was against, and I heard statements like: “Teacher, we didn't understand anything, we don't know what we are supposed to do, you didn't explain well." In the early stages, I explained again and again, and found myself formulating for students their research questions and their hypotheses. When the same repeated at the stage of processing of the paper, I took a deep breath and told them that at the next lesson, each group would work on processing the paper, and I and other students [preservice teachers] would come and help them. The class calmed down. At the next lesson I arrived with four other students. Each sat with one group. I saw that some of the groups understood the assignment, were very motivated to work on the task, were committed to the group, and didn't need guidance, whereas other groups needed close supervision.

- The satisfaction of the students, when they finished their inquiry assignment and presented the work to the class, was very exciting and satisfying.

- $\quad$ Frustration, despair. I felt that I hadn't been able to identify the source of the students' resistance. I couldn't point at the difficulty that led to their opposition.

- I understood that the students' repeated questions stemmed from the fear of experimenting. It's like a person who wants to learn to swim but outside the water. He wants clear instructions, but refuses to step into the water, because he's afraid of drowning. If he learns to swim, the fear of drowning may disappear, but as long as he refuses to experience swimming in the water, he won't learn to swim.

5) Did the process of the inquiry-based learning in a blended course help you shape your role as a teacher in the digital age?

Examples of answers:

- Exposure to the products of other students spawned a discussion in the forum on the course site. I enjoyed the experience of a learning community, of development. I found that many students encountered the same questions and difficulties that I faced in the process of inquiry.

- The blended course enabled us, the students, to engage in a stimulating and fruitful discussion, to share learning materials, to share ideas, and to cope with difficulties.

- Students brought to the site many materials they had found on the Internet. In the forum we discussed the materials and the assignments, and together we succeeded in achieving wonderful products.

- When I understood that salvation would not come from the lecturer, I decided to act: I went to the course site and found that more students were as undecided as I was, and that other students helped and guided them, and then I felt motivated and confident of being able to cope with the difficulties. The course site helped me a lot.

- I saw how the course site helped me in the process of inquiry, so I opened a site for my students, the class where I was teaching with inquiry-based learning. The site was active, they shared sites where relevant materials could be found, helped each other formulate a research question. It made me very happy and gave me a sense of satisfaction.

6) No differences were found between genders, ages, and other demographic variables.

\section{Discussion}

This study focused on preservice teachers studying to be teachers of social sciences. They participated in a blended course to develop skills in the inquiry-based learning approach, and in parallel, acquired experience teaching with this method in high school.

The findings show that most preservice teachers had a positive attitude toward inquiry-based learning, and that between the two points of measurement, when the questionnaires were administered, there was a positive trend 
and a change in attitude toward inquiry-based learning and teaching. Preservice teachers reported a sense of freedom to learn, independence, freedom of thought, and creativity at a higher level in inquiry-based learning than in learning by other methods to which they were exposed. Most of them, however, mentioned difficulties they encountered in implementing the method when teaching in school. Having gained experience with applying inquiry-based teaching in practice in schools, preservice teachers became aware of the potential for learning with this method, but they were also exposed to the many difficulties in teaching with this method in school.

Difficulties teaching in school, from the point of view of preservice teachers, following their experience of teaching with the inquiry-based method.

Circumscribing the topic. Respondents mentioned the difficulty in circumscribing the topic and defining it so that it interests the students, provokes their curiosity, and give them a desire to engage in a process of research. The definition of research is derived from the curricular subject matter by delimiting and defining a topic, but it must be open enough to require a broad field of inquiry. For example, the preservice teacher delimited the topic: human rights, freedom of expression vs the right to privacy on social networks. The preservice teacher thought that this subject was interesting, ethical, and educational, especially given the shaming taking place on the social network of the class. When the class learned about human rights through discussions and analysis of dilemmas, the preservice teacher felt that the subject interested the students and stimulated their thinking process, so he expected the students to be happy to research the subject. To his surprise, there was opposition in the class: some students said that they did not want to study by the inquiry-based method; some said that the topic did not interest them and refused to research it, and suggested other topics. One group suggested to study the profiles of the active participants in the group on the class social network and compare it with the profiles of participants not active in the group. The preservice teacher tried to nudge the students toward a different formulation, feeling that this could lead to shaming, but the members of the group objected, entrenched themselves, and refused to cooperate.

Research question. The teacher must encourage the students to dare to formulate a research question that interests them. Researchers (Bruce \& Casey, 2012; Mäeots et al., 2008; Pedaste et al., 2015; Scanlon et al., 2011) suggest that the research question should encourage students to learn and motivate them to explore the subject. A research question that does not interest the students leads to objections, resistance to the process of inquiry, discipline problems, and more.

A research question that students formulate themselves may inspire optimism and motivation to continue, grow, and develop. But the teacher should help the student focus the research question so that it is feasible and makes possible positive feedback from the early stages of the process. As significant adults, teachers must try to stimulate the students' creativity, innovation, and originality, guide them to find new ways of thinking, show the students that the teacher is open to listening, understanding, and helping them realize their ideas. The teacher must listen with amazement when a student comes up with daring and unconventional ideas, understand the ideas together with the students, and to try to guide the student toward the realization of their ideas, without clipping their wings. When working with students, we occasionally see how they think and understand differently from adults. At times, there is a connection between thinking differently and a sense of confusion and helplessness, leading to being afraid of doing and even thinking openly. To advance the students and enable them to connect with their creativity, we must free ourselves from the vision that binds us. Listening may reveal new solutions to situations that we have already dealt with in the past.

Mediating between the students and the skills required for inquiry-based learning. The difficulty in mediating between the students and the skills required for inquiry-based learning made some preservice teachers feel that it was better to lower requirements. The teacher should remember that to motivate students to embark on a journey of exploration, they must be given a sense of a significant learning challenge. Assignments that require a range of higher learning skills - analytical, verbal, etc.-are likely to increase students' motivation to confront the tasks, and help them have meaningful learning experiences (Angeli \& Valanides, 2009; Duran, 2013; Tyner, 2014).

Evaluation of the process and of the products, and learning communities. Researchers (Liu et al., 2007; Meyers, 2008; Oriogun et al., 2005; Pittman \& Richmond, 2008; Robinson \& Hullinger, 2008; Rovai, 2007; Shea et al., 2006; Young, 2006; Young \& Bruce, 2011) have found that students who are actively involved in the learning community successfully cope with significant assignments. They are likely to have a sense of belonging as opposed to alienation and isolation, and are likely to persevere and succeed in the learning tasks. Preservice teachers pointed to the difficulty of conducting an evaluation when the inquiry process took place in learning communities, i.e., in a peer group, rather than individually. The findings revealed that $67 \%$ worried that there 
was a student who did not achieve the required goals at each stage and did not understand the content. The results show that some students find it easier to retrieve data from databases, and others are better at processing data using digital tools. In the learning community, study takes place through interaction between the learner and others, acquiring knowledge, skills, ways of thinking, etc. Students practice skills they have acquired while interacting with others. Collaborating students can enrich their knowledge by sharing their unique perspectives, ideas, and personal experiences; the process of sharing deepens their understanding. Furthermore, the perspectives of others lead to a deeper understanding of the content (Ascough, 2007; Engstrom et al., 2008; Snyder, 2009). Teachers who encourage the creation of a learning community also encourage communication between students, which is likely to lead to a process of meaningful learning (Liu et al., 2007). A meaningful evaluation is guiding, mediating, enriching, and calling for a quality dialog between the teacher and the students and between the students themselves. It helps students understand in depth the wisdom that underlies the discipline of the social sciences, as one engaged in the study the human environment. It provides exposure to a variety of approaches and theories that at times complement one another and at other times contradict one another. It creates knowledge of research principles, research methods, difficulties, and limitations of research. It promotes understanding of the complexity of human behavior, with emphasis on the individual differences between people. It assists in reading and understanding research data and finding order or regularity in phenomena by observing, measuring, and discovering connections between them, understanding the connection between research findings and their ability to make predictions, based on theories and research in the discipline. The role of the teacher is to encourage and develop the students' natural curiosity, their ability to create knowledge independently, through critical and creative thinking, which will help them understand the society in which they live. The teacher must help students enjoy the process, the successes, and the product- the learning outcome. Enjoyment is not a luxury but a deep psychological need (Branden, 1989, 1994). The absence of enjoyment and a state of emotional suffering prevent the possibility of feeling, experiencing, and fulfilling dreams. The teacher should help students focus on the process, because the process takes place in the present and may lead to change in behavior, and consequently to a permanent, long-term change (Emmons \& McCullough, 2004; Watson, 2002).

Integrating a digital environment with inquiry-based learning. All preservice teachers stated that they instructed the students how to find reliable information on the Internet and how to process the information on the computer, and $32 \%$ indicated that they had opened a site for the class they had been teaching with the inquiry-based method. Today, children and adolescents have learned the need for information, to obtain the relevant information they need to solve a problem or to satisfy curiosity or need. The school must teach students the learning skills needed to enhance their academic abilities (Christensen et al., 2008; Voogt \& Pelgrum, 2005; Zilka, 2017). Researchers (Donnelly et al., 2014; Savery, 2006) have found that the proper amount of teacher mediation in a digital environment is of great significance in guiding student learning. In the present study, most preservice teachers noted the positive effect the course site had on their learning process. Researchers have found that a blended course may enrich the learning process (Anderson et al., 2001; Garrison \& Kanuke, 2004; Groen \& Li, 2005; Zeichner \& Zilka, 2016; Zilka \& Zeichner, 2017) The present study reinforces the findings of these studies. Preservice teachers felt that the course site was a source of support and turned the class into an active learning community.

\section{Conclusion}

This study shows that it is easier for preservice teachers to learn with the inquiry-based method than to teach with it. To teach using the inquiry-based method, the teacher must master subject matter knowledge, the content (facts and concepts), as well as substantive and syntactic structures (research methods). The teacher must also be aware of the differences between the students: the encounter between the group of equals is in practice a meeting between different people that enables important opportunities for realization of values and rights that derive from cooperation (as opposed to compartmentalization). These include freedom of expression, organization, mediation, tolerance. The teacher must know how to enable student participation in the decision-making process related to the nature of the peer learning process. The teacher must also strive for the integration of all students into peer educational activities, and avoid entirely the exclusion of individual children or groups from the sphere of action and decision-making. It is therefore important to provide preservice teachers, already during the training stage, with the experience of learning and teaching, using the inquiry-based method, with the guidance and mediation of teacher educators. This study shows that there has been a positive change in the preservice teachers' perception of inquiry-based learning in the process of their learning and teaching. Following their experience in learning and teaching with this method, they were able to cope with the difficulties that arise in learning and teaching. 


\section{References}

Adler, P. A., \& Adler, P. (2008). Of Rhetoric and Representation: The Four Faces of Ethnography. The Quarterly Sociological, 49(1), 1-30. https://doi.org/10.1111/j.1533-8525.2007.00104.x

Alfieri L., Brooks P. J., Aldrich N. J., \& Tenenbaum H. R. (2011). Does discovery-based instruction enhance learning? Journal of Educational Psychology, 103, 1-18. https://doi.org/10.1037/a0021017

Anderson, T., Rourke, L., Garrison, D. R., \& Archer, W. (2001). Assessing teaching presence in a computer conferencing context. Journal of Asynchronous Learning Networks, 5(2), 1-17.

Angeli, C., \& Valanides, N. (2009). Epistemological and methodological issues for the conceptualization, development and assessment of ICT-TPCK: Advances in technological pedagogical content knowledge (TPCK). Computers \& Education, 52(1), 154-168. https://doi.org/10.1016/j.compedu.2008.07.006

Argyris, C., \& Schon, D. A. (1996). Organizational learning II: Theory, method, and practice. NY: Addison-Wesley.

Ascough, R. (2007). Welcoming design: Hosting a hospitable online course. Teaching Theology and Religion, 10(3), 131-136. https://doi.org/10.1111/j.1467-9647.2007.00340.x

Ashburn, E. A., \& Floden, R. E. (2006). Meaningful learning using technology: What educators need to know and do. New York: Teachers College Press.

Atkinson, E., \& Delamont, S. (2006). In the roiling smoke: qualitative inquiry and contested fields. International Journal of Qualitative Studies in Education, 19(6), 747-755. https://doi.org/10.1080/09518390600975974

Bai, H. (2019). Preparing Teacher Education Students to Integrate Mobile Learning into Elementary Education. TechTrends, 63, 723-733. https://doi.org/10.1007/s11528-019-00424-z

Baker, C. (2010). The impact of instructor immediacy and presence for online student affective learning, cognition, and motivation. The Journal of Educators online, 7(1), 1-30. https://doi.org/10.9743/JEO.2010.1.2

Barron, B., \& Darling-Hammond, L. (2008). Teaching for Meaningful Learning: A Review of Research on Inquiry-Based and Cooperative Learning. Stanford University.

Bhagat, A. (2017). Inquiry-based learning: Assessing students'science inquiry skills. Research Developments, ACER. Retrieved from https://rd.acer.org/article/inquiry-based-learning-assessing-students-science-inquiryskills

Billings, D., \& Halstead, J. (2009). Teaching in nursing: A guide for faculty (3rd ed.). St Louis, MI: Saunders.

Boyatzis, R. E. (1998). Transforming qualitative information: thematic analysis and code development. Newbury Park, CA: Sage.

Branden, N. (1989). The Virtue of Selfishness. New American Library.

Branden, N. (1994). The Six Pillars of Self-Esteem. Bantam Books.

Braun, V., \& Clarke, V., (2006). Using thematic analysis in psychology. Qualitative Research in Psychology, 3, 77-101. https://doi.org/10.1191/1478088706qp063oa

Bruce B. C., \& Casey, L. (2012). The practice of inquiry: A pedagogical 'sweet spot' for digital literacy? Computers in the Schools, 29(1-2), 191-206. https://doi.org/10.1080/07380569.2012.657994

Capar, G., \& Tarim, K. (2015). Efficacy of the Cooperative Learning Method on Mathematics Achievement and Attitude: A Meta-Analysis Research. Educational Sciences: Theory and Practice, 15(2), 553-559.

Chenail, R. J. (2012). Conducting Qualitative Data Analysis: Qualitative Data Analysis as a Metaphoric Process. The Qualitative Report, 17(1), 248-253. Retrieved from https://nsuworks.nova.edu/tqr/vol17/iss1/13

Chinn, C. A., Duncan, R. G., \& Rinehart, R. W. (2018). Epistemic design: Design to promote transferable epistemic growth in the PRACCIS project. In E. Manalo, Y. Uesaka, \& C. A. Chinn (Eds.), Routledge research in achievement and gifted education. Promoting spontaneous use of learning and reasoning strategies: Theory, research, and practice for effective transfer (pp. 242-259). Routledge/Taylor \& Francis Group.

Christensen, C., Horn, M. B., \& Johnson, C. W. (2008). Disruptive class: How disruptive innovation will change the way the world learns. New York: McGraw Hill.

Cole, J. (2009). Strategies for success: Teaching an online course. Rural Special Education Quarterly, 28(4), 
36-40. https://doi.org/10.1177/875687050902800406

Crabtree, B. F., \& Miller, W. L. (Eds.). (1992). Doing qualitative research. Newbury Park, CA: Sage.

De Jong, T., van Joolingen, W.R., Giezma, A., Girault I., Hoppe, U., Kindermann, J., ... Van Der Zanden, M. (2010). Learning by creating and exchanging objects: the SCY experience. British Educational Research Association, 41(6), 909-921. https://doi.org/10.1111/j.1467-8535.2010.01121.x

Desimone, L. M. (2009). Improving Impact Studies of Teachers' Professional Development: Toward Better Conceptualizations and Measures. Educational Researcher (ER), 38(3), 181-199. https://doi.org/10.3102/0013189X08331140

Dewey, J. (1938). Experience and education. The Educational Forum, 50(3), 241-252. https://doi.org/10.1080/00131728609335764

Donnelly, D. F., Linn, M., \& Ludvigsen, S. (2014). Impacts and characteristics of computer-based science inquiry learning environments for precollege students. Review of Educational Research, 84(4), 572-608. https://doi.org/10.3102/0034654314546954

Durish, P. (Ed.). (2013). Information technology programs: Successes and challenges. Birmingham: The Haworth Press.

Emmons, R. A., \& McCullough, M. E. (2004). The Psychology of Gratitude. Oxford University Press.

Engstrom, M., Santo, S., \& Yost, R. (2008). Knowledge building in an online cohort. The Quarterly Review of Distance Education, 9(2), 151-167.

Ertmer, P. A., \& Ottenbreit-Leftwich, A. T. (2010). Teacher technology change: How knowledge, confidence, beliefs, and culture intersect. Journal of Research on Technology in Education, 42(3), 255-284. https://doi.org/10.1080/15391523.2010.10782551

Feenberg, A. (2010). Between reason and experience: Essays in technology and modernity. Cambridge. MA: Cambridge MIT Press. https://doi.org/10.7551/mitpress/8221.001.0001

Feldman, K. A. (2007). Identifying exemplary teachers and teaching: Evidence from student ratings. In R. P. Perry, \& J. C. Smart (Eds.), The scholarship of teaching and learning in higher education. An evidence-based perspective (pp. 93-143). New York: Springer.

Furtak E. M., Seidel T., Iverson H., \& Briggs D. C. (2012). Experimental and quasi-experimental studies of inquiry-based science teaching. Review of Educational Research, 82, 300-329. https://doi.org/10.3102/0034654312457206

Garrison, R., \& Kanuke, H. (2004). Blended learning: Uncovering its transformative potential in higher education. The Internet and Higher Education, 7, 95-105. https://doi.org/10.1016/j.iheduc.2004.02.001

Gillies, R., \& Ashman, A. (2013). The social and intellectual outcomes of learning in groups. London: Routledge Falmer.

Groen, J., \& Li, Q. (2005). Achieving the benefits of blended learning within a fully online learning environment: A focus on synchronous communication. Educational Technology, 45(6), 31-37.

Hammersley, M. (2008). Questioning Qualitative Research: Critical Essays. London, UK: Sage. https://doi.org/10.4135/9780857024565

Holmes, W., Anastopoulou, s., Schaumburg, H., \& Mavrikis, M. (2018). Technology-enhanced Personalised Learning: Untangling the Evidence. Stuttgart: Robert- Bosch-Stiftung GmbH.

Husaj, S. (2016). Social Emotional Learning (SEL). European Journal of Multidisciplinary Studies, 1(3), 168-171. https://doi.org/10.26417/ejms.v1i3.p168-171

Jelfs, A., Richardson, J. T. E., \& Price, M. J. (2009). Student and tutor expectations of effective tutoring in distance education. Distance Education, 30(3), 419-435. https://doi.org/10.1080/01587910903236551

Kennedy, M. M. (2016). How Does Professional Development Improve Teaching? Review of Educational Research (RER), 86(4), 945-980. https://doi.org/10.3102/0034654315626800

Kirschner, P. A., \& Van Merriënboer, J. J. G. (2013). Do Learners Really Know Best? Urban Legends in Education. Educational Psychologist, 48(3), 169-183. https://doi.org/10.1080/00461520.2013.804395

Kirschner, P. A., Sweller, J., \& Clark, R. E. (2006). Why Unguided Learning Does Not Work: An Analysis of the Failure of Discovery Learning, Problem-Based Learning, Experiential Learning and Inquiry-Based 
Learning. Educational Psychologist, 41, 75-86. https://doi.org/10.1207/s15326985ep4102_1

Lampert, M. (2010). Learning Teaching in, from, and for Practice: What Do We Mean? Journal of Teacher Education, 61(1-2), 21-34.

Lawrence, J., \& Sankey, M. (2008). Communities of practice: A sphere of influence enhancing teaching and learning in higher education. Paper presented at Australian and New Zealand Communication Association Conference 2008. Retrieved from http://eprints.suq.edu.au/42681/Lawrence_Sankey_ANZCA2008.pdf

Lee, C. (2008). A neophyte about online teaching. Qualitative Inquiry, 14(7), 1180-1186. https://doi.org/10.1177/1077800408322226

Liu, X., Magjuka, R. J., Bonk, C. J., \& Lee, S. (2007). Does sense of community matter? An examination of participants' perceptions of building learning communities in online courses. The Quarterly Review of Distance Education, 8(1), 9-24.

Loyens, S. M. M. \& Rikers, R. M. J. P. (2011). Instruction Based on Inquiry. In R. E. Mayer, \& P. A. Alexander (Eds.), Handbook of Research on Learning and Instruction (pp. 361-381). New York: Routledge Press.

Mäeots, M., Pedaste, M., \& Sarapuu, T. (2008). Transforming students' inquiry skills with computer-based simulations. 8th IEEE International Conference on Advanced Learning Technologies, 1-5 July. https://doi.org/10.1109/ICALT.2008.239

Mäeots, M., Pedaste, M., \& Sarapuu, T. (2011). Interactions between inquiry processes in a Web-based learning environment. 11th IEEE International Conference on Advanced Learning Technologies, 6-8 July. https://doi.org/10.1109/ICALT.2011.103

Mahler, D. (2012). Teaching literacy in primary schools using an interactive whole-class technology: Facilitating student-to student whole-class dialogic interaction. Technology, Pedagogy and Education, 21(1), 137-152. https://doi.org/10.1080/1475939X.2012.659888

Maurice, J. E., \& Harriett, A. (Eds.). (2006). The Educator's Guide to Emotional Intelligence and Academic Achievement Social-Emotional Learning in the Classroom. Saga Corwinpress, California.

McDonald, M., Kazemi, E., \& Kavanagh, S. S. (2013). Core Practices and Pedagogies of Teacher Education A Call for Common Language and Collective Activity. Journal of Teacher Education, 64(5), 378-386. https://doi.org/10.1177/0022487113493807

Meyers, S. (2008). Using transformative pedagogy when teaching online. College Teaching, 56(4), 219-224. https://doi.org/10.3200/CTCH.56.4.219-224

Minner, D. D., Levy, A. J., \& Century, J. (2010). Inquiry-based science instruction-what is it and does it matter? Results from a research synthesis years 1984 to 2002. Journal of Research in Science Teaching, 47, 474-496. https://doi.org/10.1002/tea.20347

Nir, A., Ben-David, A., Bogler, R., Inbar, D., \& Zohar, A. (2016). School autonomy and 21st century skills in the Israeli educational system. International journal of educational management.

OECD. (2019). TALIS 2018 Results (Volume I): Teachers and school leaders as lifelong learners, TALIS. Paris: OECD Publishing.

Oliver, K., Osborne, J., \& Brady, K. (2009). What are secondary student's expectations for teachers in virtual school environments? Distance Education, 30(1), 23-45. https://doi.org/10.1080/01587910902845923

Oriogun, P. K., Ravenscroft, A., \& Cook, J. (2005). Validating an approach to examining cognitive engagement within online groups. The American Journal of Distance Education, 19(4), 197-214. https://doi.org/10.1207/s15389286ajde1904_2

Pea, R. D. (1993). Practices of Distributed Intelligence and Designs for Education. In G. Salomon (Ed.), Distributed Cognitions Psychological and educational considerations (pp.47-87). New York: Cambridge University Press.

Pedaste, M., Mäeots, M., Leijen, Ä., \& Sarapuu, T. (2012). Improving students' inquiry skills through reflection and self-regulation scaffolds. Technology, Instruction, Cognition and Learning, 9(1-2), 81-95.

Pedaste, M., Mäeots, M., Siiman, L. A., de Jong, T., van Riesen, S. A., Kamp, E. T., ... Tsourlidaki, E. (2015). Phases of inquiry-based learning: Definitions and the inquiry cycle. Educational research review, 14, 47-61. https://doi.org/10.1016/j.edurev.2015.02.003

Pittman, L. D., \& Richmond, A. (2008). University belonging, friendship quality, and psychological adjustment 
during the transition to college. The Journal of Experimental Education, 76(4), 343-361. https://doi.org/10.3200/JEXE.76.4.343-362

Robinson, C. C., \& Hullinger, H. (2008). New benchmarks in higher education: Student engagement in online learning. Journal of Education for Business, 2, 101-108. https://doi.org/10.3200/JOEB.84.2.101-109

Rovai, A. P. (2007). Facilitating online discussions effectively. The Internet \& Higher Education, 10(1), 77-88. https://doi.org/10.1016/j.iheduc.2006.10.001

Rovai, A., Wighting, M. J., \& Lucking, R. (2004). The classroom and school community inventory: Development, refinement and validation of a self-report measure for educational research. Internet and Higher Education, 7(4), 263-280. https://doi.org/10.1016/j.iheduc.2004.09.001

Salman, E. (2006). Taxonomy of collaborative e-learning. Cincinnati, OH: Union Institute \& University.

Savery, J. R. (2006). Overview of problem-based learning: Definitions and distinctions. Interdisciplinary Journal of Problem-Based Learning, 1(1), 9-20. https://doi.org/10.7771/1541-5015.1002

Scanlon, E., Anastopoulou, S., Kerawalla, L., \& Mulholland, P. (2011). How technology resources can be used to represent personal inquiry and support students' understanding of it across contexts. Journal of Computer Assisted Learning, 27(6), 516-529. https://doi.org/10.1111/j.1365-2729.2011.00414.x

Schwab, J. J. (1962). The teaching of science as enquiry. In J. J. Schwab, \& P. F. Brandwein (Eds.), The Teaching of Science. Cambridge, Massachusetts. Harvard University Press.

Sharan, Y., (2014). Learning to cooperate for cooperative learning. Anales de Psicologia, 30(3), 802-807. https://doi.org/10.6018/analesps.30.3.201211

Shea, P., Li, C. S., \& Pickett, A. (2006). A study of teaching presence and student sense of learning community in fully online and web-enhanced college courses. The Internet and Higher Education, 9(3), 175-190. https://doi.org/10.1016/j.iheduc.2006.06.005

Snyder, M. M. (2009). Instructional-design theory to guide the creation of online learning communities for adults. TechTrends, 53(1), 48-56.

Splitter, L. J. (2009). Authenticity and constructivism in education. Studies in Philosophical Education, 28(2), 135-151. https://doi.org/10.1007/s11217-008-9105-3

Sung, Y. T., Chang, K. E., \& Liu, T. C. (2016). The effects of integrating mobile devices with teaching and learning on students' learning performance: A meta-analysis and research synthesis. Computers and Education, 94, 252-275. https://doi.org/10.1016/j.compedu.2015.11.008

Tsai, P., \& Tsai, C. (2019). Preservice teachers' conceptions of teaching using mobile devices and the quality of technology integration in lesson plans. British Journal of Educational Technology, 50(2), 614-625. https://doi.org/10.1111/bjet.12613

Tyner, K. (2014). Literacy in a digital world: Technology and learning in the age of information. Mahwah, NJ: Erlbaum. https://doi.org/10.4324/9781410601971

Voogt, J., \& Pelgrum, H. (2005). ICT and curriculum change. Human Technology: An Interdisciplinary. Journal on Humans in ICT Environments, 1, 157-175. https://doi.org/10.17011/ht/urn.2005356

Vygotsky, L. (1989). Thought and language. Cambridge, MA: MIT Press.

Watson, D. (2002) .Positive Affectivity: The Disposition to Experience Pleasurable Emotional States. In C. R. Snyder, \& S. J. Loper (Eds.), Handbook of Positive Psychology. Qxford University Press.

Weick, K. (1997). The social Psychology of organizing (2nd edition) Reading, MA; Edison-Wesley Publishing Co.

Young, S. (2006). Student views of effective online teaching in higher education. The American Journal of Distance Education, 20(2), 65-77.

Young, S., \& Bruce, M. A. (2011). Classroom Community and Student Engagement in Online Courses. Journal of Online Learning and Teaching, 7(2). Retrieved from http://jolt.merlot.org/vol7no2/young_0611.htm

Zeichner, O., \& Zilka, C. G. (2016). Feelings of Challenge and Threat among Pre-Service Teachers Studying in Different Learning Environments-Virtual vs. Blended Courses. Journal of Educational Technology, 13(1), 7-19.

Zilka, C. G. (2017). Awareness of ICT capabilities, digital literacy, and use of reflective processes in children 
who received their first home computer. Journal of Technology Enhanced Learning, 9(1), 80-98. https://doi.org/10.1504/IJTEL.2017.084074

Zilka, C. G. (2020a). Social presence in blended course forums in the training of preservice teachers. International Journal of Mobile and Blended Learning (IJMBL), 12(4).

Zilka, C. G. (2020b). The experience of receiving and giving public oral and written peer feedback on the teaching experience of preservice teachers. In M. Jones (Ed.), Proceedings of InSITE 2020: Informing Science and Information Technology Education (pp 1-13). Informing Science Institute. https://doi.org/10.28945/4502

Zilka, C. G., \& Zeichner, O. (2017). Forums and Critical Factors Involved in Feelings of Challenge and Threat among Preservice Teachers Studying Virtual and Blended Courses. Journal of Educational Technology, 13(4), 1-13.

Zilka, C. G., \& Zeichner, O. (2019). Factors necessary for engaging preservice teachers studying in virtual and blended courses. International Journal of Mobile and Blended Learning (IJMBL), 11(1), 42-57. https://doi.org/10.4018/IJMBL.2019010104

Zilka, C. G., Cohen, R., \& Rahimi, D. I. (2018). Teacher Presence and Social Presence in Virtual and Blended Courses. Journal of Information Technology Education: Research, 17, 103-126. https://doi.org/10.28945/4061

Zilka, C. G., Rahimi, D. I., \& Cohen, R. (2019). Sense of challenge, threat, self-efficacy, and motivation of students learning in virtual and blended courses. American Journal of Distance Education, 33(1), 2-15. https://doi.org/10.1080/08923647.2019.1554990

Zins, J. E. (Ed.). (2004). Building Academic Success on Social and Emotional Learning: What Does the Research Say? (The Series on Social Emotional Learning). Teachers College Press, New-York \& London.

\section{Copyrights}

Copyright for this article is retained by the author(s), with first publication rights granted to the journal.

This is an open-access article distributed under the terms and conditions of the Creative Commons Attribution license (http://creativecommons.org/licenses/by/4.0/). 